\title{
PENYULUHAN MANAJEMEN SUMBER DAYA MANUSIA UNTUK PENGEMBANGAN KARANG TARUNA DENPASAR TIMUR BALI
}

\author{
${ }^{1 *}$ Irfan Rizka Akbar, ${ }^{2}$ Andry Septianto, ${ }^{3}$ Ibnu Sina, ${ }^{4}$ Nofiar, ${ }^{5}$ Maswarni \\ Universitas Pamulang Tangerang Selatan, Banten, Indonesia \\ Email : *dosen02461@unpam.ac.id
}

Manuskrip: Juni -2021; Ditinjau: Juni -2021; Diterima: Juli -2021;

Online: Juli-2021; Diterbitkan: Juli-2021

\begin{abstract}
ABSTRAK
Karang Taruna merupakan organisasi social yang beranggotakan para remaja, disini remaja dapat mengembangkan diri sesuai potensi masing-masing. Dan merupakan organisasi social dalam masyarakat sehingga perannya memang membantu masyarakat setempat. Untuk itu perlu pembinaan berkelanjutan agar para remaja tumbuh berkembang menjadi manusia dewasa yang berkualifikasi.

Metode pelaksanaan dalam kegiatan program pengabdian kepada masyarakat ini diawali dengan melakukan pendekatan kepada ketua Karang Taruna Denpasar Timur Bali. Dari hasil surve awal melalui wawancara pada dasarnya keberadaan Karang Taruna Denpasar Timur untuk membantu masyarakat Bali di bidang pendidikan, seni, social dan ekonomi

Hasil pengabdian masyarakat yang diperoleh adalah terbukanya pemikiran yang lebih terdepan dalam pengembangan manajemen sumber daya manusia dalam pemanfaatan sumber daya karang taruna di pengembangan usaha silver di Bali.

\section{Kata Kunci: SDM, Karang Taruna}

\section{PENDAHULUAN}

Dewasa ini sumber daya manusia bukan semata-mata sumber daya, tetapi lebih dari aset bagi organisasi, atau istilahnya adalah human capital. Artinya, aset bernilai yang dapat dikembangkan sebagai investasi bagi organisasi. Manajemen sumber daya manusia sangat penting mengingat dengan perkembangan teknologi dan informasi saai ini cenderung mengkondisikan dalam menjalankan organisasi berdasarkan sistem atau lebih dikenal dengan Management by system. Keberadaan sumber daya manusia seakan ke geser tergantikan sistem, maka dari itu sebagai penggerak, dan pondasi dalam menjalankan organisasi posisi sumber daya manusia tidak boleh kalah dengan sistem. Sumber daya manusia harusnya yang menciptakan sistem untuk membantu memudahkan dan meringankan pekerjaan manusia bukan dikendalikan oleh sistem. Pada hakikatnya sumber daya manusia merupakan penggerak, pemikir, dan perencana untuk mencapai tujuan organisasi. Masa era globalisasi seperti sekarang ini, menuntut kualitas sumberdaya manusia dengan berbagai potensi agar siap menghadapi tingkat persaingan yang semakin kompetitif.
\end{abstract}


Manajemen merupakan seni dan ilmu mengelola suatu organisasi yang mengatur proses pemanfaatan sumber daya manusia dan sumber daya yang lain secara efektif dan efisien untuk mencapai tujuan., Atau secara rinci merupakan proses mulai dari perencanaan, pengorganisasian, pelaksanaan, pengendalian, sampai evaluasi hasil yang dilakukan secara efektif dan efisien dalam mencapai tujuan organisasi. Jika manajemen diaplikasikan dalam lembaga social di masyarakat seperti Karang Taruna, maka dapat diartikan sebagai suatu proses pengelolaan organisasi social masyarakat secara efektif dan efisien untuk mencapai tujuan akan keberadaan Karang Taruna. Tujuan yang ingin dicapai tentu merupakan tujuan yang mendatangkan manfaat banyak orang dalam masyarakat terkait.

Dengan begitu manajemen sumber daya manusia juga dapat diartikan sebagai ilmu yang mengatur manusia dalam suatu organisasi sebagai pondasi untuk mencapai tujuan. Tujuan utama manajemen sumber daya manusia yaitu untuk memaksimalkan sumber daya ekonomi yang memiliki rasa dan karsa untuk menjalankan suatu organisasi social dalam wadah Karang Taruna. Dengan membangun manajemen sumberdaya manusia yang baik dalam organisasi dapat memudahkan pencapaian tujuan. Manaejmen diperlukan untuk daya guna, hasil guna organisasi dan unsur-unsur manajemen. Dapat digarisbawahi bahwa sumber daya manusia merupakan penggerak organisasi dan berfungsi secara aset yang harus dilatih dan dikembangkan kemampuannya.

Pengembangan merupakan suatu cara efektif untuk menghadapi beberapa tantangan yang dihadapi. Kemampuan mengatasi tantangan merupakan factor yang mempengaruhi keberhasilan organisasi dalam mempertahankan eksistensinya. Pengembangan sumber daya manusia bertujuan menghasilkan kerangka yang secara logis dan komprehensif mengembangkan organisasinya agar bermanfaat bagi organisasi dan masyarakat (Handoko, 2012). Pengembangan sumber daya manusia juga sebagai upaya berkesinambungan meningkatkan mutu sumber daya manusia melalui pendidikan, pelatihan dan pembinaan (Sutrisno, 2014). Siapa yang perlu diberikan pendidikan, pelatihan dan pembinaan dalam organisasi social karang taruna? Tentu para remaja anggota karang taruna yang perlu di latih dan dibina gar mempunyai cukup bekal sebagai sumber daya manusia yang kompeten. Karena di pundak para remaja anggota karang taruna terdapat tanggungjawab yang besar sebagai generasi penerus pengisi kemerdekaan bangsa Indonesia. Generasi yang tangguh, terampil dan berakhlak mulia serta memiliki integritas yang tinggi merupakan dambaan semua kalangan. Berangkat dari krisis multidimensional yang dialami oleh bangsa ini sudah sepatutnya mempersiapkan generasi tersebut sebagai penerus dari estafet kepemimpinan di negeri ini. Akibat dari krisis moral ini banyak generasi muda mengalami nasib kurang beruntung, putus sekolah, terkena kasus narkoba, dan masih banyak kasus kriminal lainnya. Oleh karena itu, program pengembangan hendaknya dilakukan secara berkesinambungan dan berpedoman kepada keterampilan yang dibutuhkan organisasi untuk masa yang akan datang. Pengembangan harus bertujuan untuk 
meningkatkan kemampuan teknis, teoritis, konseptual, dan moral supaya produktivitas.

Karang taruna merupakan wadah pengembangan diri yang sangat positif mengingat dewasa ini sebagai dampak negative dari perkembangan teknologi informasi dan komunikasi sangat disayangkan jika para remaja terbawa arus pergaulan yang salah. Sudah banyak kejadian, akibat salah pergaulan para remaja lupa akan kewajiban dan tanggung jawabnya sebagai generasi penerus bangsa. Hal-hal semacam ini yang menyebabkan rendahnya kualitas sumber daya manusia. Semua tidak terlepas dari lingkungan yang membentuk karakter para remaja. Artinya, jika lingkungan pergaulannya salah maka akibatnya juga kurang baik. Lingkungan yang paling mendasar adalah lingkungan keluarga.dan masyarakat merupakan lingkungan sosialnya. Keluarga merupakan lingkungan terdekat untuk membesarkan, mendewasakan, dan di dalamnya mendapatkan pendidikan pertama kali. Karena itu keluarga mempunyai peran yang penting dalam perkembangan remaja. Keluarga yang baik akan memberikan pengaruh positif bagi remaja, sebaliknya keluarga yang kurang baik akan memberi pengaruh negatif.

Secara umum Karang taruna merupakan suatu organisasi kepemudaan di Indonesia sebagai wadah pengembangan jiwa sosial generasi muda. Karang taruna tumbuh atas kesadaran dan rasa tanggung jawab sosial dari masyarakat dan untuk masyarakat itu sendiri khususnya generasi muda yang ada di suatu wilayah desa, kelurahan atau komunitas yang sederajat, terutama bergerak pada bidang-bidang kesejahteraan sosial (Wenti, 2013). Seperti bidang ekonomi, olahraga, keterampilan, keagamaan dan kesenian sesuai dengan tujuan didirikannya karang taruna untuk memberikan pembinaan dan pemberdayaan kepada para remaja di suatu desa atau wilayah itu sendiri. Sebagai organisasi sosial kepemudaan Karang Taruna merupakan wadah atau tempat pembinaan dan pengembangan dalam upaya mengembangkan kegiatan ekonomi, sosial, budaya dengan memanfaatankan semua potensi yang ada di lingkungan masyarakat, baik sumber daya manusia maupun sumber daya alam yang telah tersedia.

Begitu halnya Karang Taruna Denpasar Timur merupakan wadah atau organisasi kepemudaan ditingkat Rukun Warga (RW) di Desa Denpasar Timur guna mewadahi kegiatan remaja putra putri untuk mengembangkan minat bakatnya melalui program kegiatan yang diagendakan oleh pengurus yang disusun melalui program kerja. Itulah sebabnya subyek dari kegiatan pengabdian kepada masyarakat ini adalah Karang Taruna Denpasasr Timur Bali dimana anggota Karang Taruna merupakan bagian dari masyarakat sebagai penyambung lidah untuk diteruskan kepada keluarganya ataupun masyarakat luas. Pertimbangan lainnya, karena keanggotaan dari Karang Taruna adalah remaja atau pemuda, selain memberikan kegiatan yang positif juga dirasa perlu untuk mendapatkan tambahan pengetahuan, ketrampilan dan pengarahan dalam rangka menyiapkan generasi penerus bangsa yang berkualitas.

Denpasar Timur merupakan bagian dari kepulauan Bali yang bisa dibilang masyarakatnya masih belum maju dan perlu perhatian dari pemerintah daerah setempat. Secara structural desa merupakan pemerintahan terkecil dari suatu 
Negara. Untuk membangun desa diperlukan membangun sumber daya manusia terlebih dahulu, karena sumber daya manusia merupakan pondasi dan penggerak dari suatu organisasi. Maju tidaknya suatu wilayah tergantung pada sumber daya manusianya. Jika dalam suatu masyarakat sumber daya manusia produktif maka daearh tersebut juga akan lebih maju dibanding dengan daerah yang sumber daya manusia kurang produktif atau kurang berkualitas. Berkembang tidaknya suatu Negara dapat dicerminkan dari maju tidaknya wilayah desa, artinya kalau desanya maju dan makmur pasti wilayah di atasnya seperti kecamatan, kota, propinsinya juga maju dan makmur. Maka dari itu kemakmuran suatu Negara juga dapat diukur dari tingkat kemamkmuran desanya. Itulah sebabnya perlu bersinergi dalam membangun desa antar aparat pemerintah desa dengan masyarakat setempat untuk bersama-sama berkolaborasi membangun dan memajukan desanya, dalam hal ini adalah Denpasar Timur Bali.

Kepengurusan Karang Taruna Denpasar Timur dilakukan pergantian secara berkala periode tiga tahunan itu merupakan organisasi social yang kegiatannya berdasarkan hasil rapat kerja untuk menyusun program-program sesuai dengan perkembangan wilayah Denpasar Timur Bali. Pemilihan yang melibatkan ketua RT dan RW baru pertama kali dilakukan, sebelumnya dengan cara musyawarah besar bersama Kepala Desa dan tokoh pemuda. Pemilihan Ketua Karang Taruna dilakukan pada Minggu, 14 Oktober 2018 untuk periode 2018 - 2021. Pola pemilihan seperti ini mendapat apresiasi dari Kepala Desa karena mencerminkan proses pemilihan secara demokrasi, penuh kebersamaan guna bersama-sama, berkolaborasi dan bersinergi membangun wilayah Denpasar Timur. Hendra Wahyudi sebagai ketua terpilih juga menyampaikan bahwa pemuda pemudi melalui wadah karang taruna bisa bekerja sama untuk memajukan Denpasar Timur Bali. Hendra Wahyudi bersama timnya yang beranggotakan 38 remaja telah berkomitmen mengembangkan dan memajukan Denpasar Timur Bali.

Berdasarkan peran dan fungsi Karang Taruna Denpasar Timur yang banyak membantu dan berkontribusi pada masyarakat, sudah selayaknya dapat perhatian dari semua pihak agar organisasi karang taruna dapat menjalankan peran dan fungsinya secara optimal. Apalagi anggotanya adalah para remaja yang secara kepribadian juga belum dapat dikatakan matang, dengan kata lain belum stabil, sehingga masih mudah dipengaruhi. Dengan mereka aktif dalam ke organisasian seperti karang taruna akan sangat membantu pembentukan karakter kepemimpinan yang mempunyai tanggung jawab, dedikasi yang tinggi, bekerja dengan tim dan berani mengambil risiko. Pembentukan karakter harus dimulai dari dini, artinya mulai anak-anak perlu ditumbuhkan dasar-dasar kepemimpinan dan kerja tim. Karang taruna merupakan alternative yang tepat untuk tumbuh kembang remaja untuk memberikan kegiatan positif agar tidak terbawa arus pergaulan yang salah.

Kehadiran tim dosen pengusul pengabdian kepada masayrakat dari Universitas Pamulang diharapkan dapat menjadi mediator dalam pengembangan program-program yang sudah disusun Karang Taruna Denpasar Timur ataupun menjadi pembina dalam pengembangan program kegiatan. Oleh karena itu pada kesempatan ini, tim pengusul ingin memberikan penyuluhan dengan tema 
"Manajemen sumber daya manusia untuk pengembangan Karang Taruna Denpasar Timur Bali

\section{METODE PELAKSANAAN KEGIATAN}

Metode pelaksanaan dalam kegiatan program pengabdian kepada masyarakat ini diawali dengan melakukan pendekatan kepada ketua Karang Taruna Denpasar Timur Bali. Surve awal yang dilakukan oleh tim pengusul untuk menjajaki dan mengetahui permasalahan yang ada di internal karang taruna dan masyarakat sekitarnya. Dari hasil surve awal melalui wawancara dengan Saudara Diky Zulkarnain selaku ketua Karang Taruna Denpasar Timur, disampaikan pada dasarnya keberadaan Karang Taruna Denpasar Timur untuk membantu masyarakat Denpasar di bidang pendidikan, seni, social dan ekonomi.

Karang Taruna yang basecamp nya berlokasi di Villa Dago memang relative lebih dekat dengan Kelurahan Benda Baru dengan harapan agar lebih mudah melakukan koordinasi dengan pihak kelurahan. Dengan pengurus sebanyak 32 orang diharapkan sudah cukup untuk mengembangkan beberapa bidang untuk meningkatkan kemampuan mereka agar bisa membantu masyarakat setempat. Seperti yang disampaikan Ketua Karang Taruna Denpasar Timur Bali, bahwa bersama jajaran pengurus akan menggerakkan kembali Karang Taruna Denpasar Timur Bali pada skala yang lebih luas agar masyarakat yang terbantu juga lebih banyak. Melalui program kerja yang telah disesuaikan dengan perkembangan wilayah Denpasar Timur, yang dihasilkan dari rapat kerja akan melakukan kegiatan yang telah diprogramkan tersebut dengan sungguh-sungguh agar tujuan dari organisasi ini dapat dicapai. Ketua Karang Taruna melihat masih banyak yang harus dibenahi dan ditingkatkan, seperti paradikma tentang pendidikan yang masih rendah, peningkatan kualitas ekonomi dan masih banyak lagi permasalahan yang perlu penanganan serius. Maka dari itu sebagai pemuda tidak hanya sebagai penonton, melainkan harus berpartisipasi dan berkontribusi pada masyarakat dengan membantu melakukan program pembangunan Wilayah Denpasar.

Adapun metode pelaksanaan program kemitraan masyarakat sebagai berikut:

1. Tahap Pemilihan Lokasi Pengabdian

Tahap pemilihan lokasi pengabdian kepada masyarakat tentu harus mempertimbangkan banyak hal. salah satunya adalah kebutuhan masyarakat yang merupakan objek dari pengabdian. Karang Taruna Denpasar Timur Bali menjadi lokasi pilihan karena melihat karang taruna ini aktif dan antusias untuk mengembangkan organisasinya dan memajukan wilayah Denpasar Timur. Respon ketua dan jajaran pengurusnya untuk menerima masukan, atau wawasan baru sangat welcome, artinya responnya sangat positis saat tim pengusul berkunjung dan bersilaturrohim serta menyampaikan tujuan kedatangan tim pengusul. Artinya, Karang Taruna Denpasar Timur dapat bersinergi dengan civitas akademika untuk bersama-sama membangun masyarakat baik dari bidang pendidikan, seni, budaya, social maupun sumber daya manusia. 


\section{Tahap Pengusulan}

Setelah tim pengusul melakukan observasi awal dan sudah mengidentifikasi permasalahan pada objek pengabdian kepada masyarakat, maka dapat ditentukan temanya atau judulnya. Selanjutnya berdasarkan tema tersebut disusunlah proposal pengabdian kepada masyarakat yang diajukan melalui program Sintias. Program Sintias merupakan program pengusulan penelitian dan pengabdian kepada masyarakat bagi dosen yang akan melakukan tridharma perguruan tinggi. Setelah diusulkan dan di unggah melalui web.sintias.unpam.ac.id akan dikirim ke reviewer oleh pihak LPPM Universitas Pamulang. Setelah mendapat persetujuan dari reviewer kegiatan dapat dilaksakan dengan mendapatkan surat tugas, kontrak penelitian / pengabdian, surat pengantar yang semuanya dapat dilakukan sendiri oleh dosen dengan mendownload dokumen apa yang dibutuhkan, termasuk sertifikat juga sudah disiapkan di sistem Sintias LPPM Universitas Pamulang.

Pada sistem Sintias ini sudah disiapkan template penelitian dan template pengabdian kepada masyarakat. Jadi pengusul tinggal mengisikan sesuai template dan mengikuti ketentuan yang berlaku dalam pengisisn template. Hal ini dimaksudkan untuk memudahkan pengususl dan pihak LPPM untuk merencanakan, melaksanakan, monitoring hasil dan melakukan evaluas terhadap dosen yang melaksanakan tridharma Perguruan TInggi.

3.Tahap Pengumpulan data

Pengumpulan data yaitu mengumpulkan data di lokasi pengabdian dengan melakukan konsultasi, observasi, wawancara, dan dokumentasi dengan menentukan strategi pengumpulan data yang dipandang tepat untuk menentukan tema atau fokus serta pendalaman data pada proses pengumpulan data berikutnya. Pada tahap pengumpulan data ini ditujukan untuk mengidentifikasi permasalahan yang dihadapi atau tema yang dibutuhkan oleh warga / masyarakat. Dari hasil surve dan wawancara dengan ketua Karang Taruna Denpasar Timur diperoleh data permasalahan bahwa memang perlu pengetahuan dan wawasan baru untuk mengembangkan organisasi dan meningkatkan kualitas sumber daya manusia anggota. Untuk selanjutnya dapat dikembangkan lagi pada masyarakat yang lebih luas. Selain melakukan wawancara awal dengan ketua karang taruna tentu juga melakukan observasi pada masyarakat setempat untuk memastikan bahwa permasyalahan atau kebutuhan masyarakat setempat sesuai dengan hasil konsulidasi dengan ketua Karang Taruna Denpasar Timur. Pengumpulan data awal tentunya tidak cukup dengan bersumber dari satu informasi tetapi juga crosscek dengan masyarakat setempat agar program pengabdian kepada masyarakat ini tepat sasaran dan tepat guna.

4.Tahap Persiapan Pelaksanaan

Tahap persiapan ini, dilakukan koordinasi secara intensif dengan anggota (tim) agar pelaksanaan kegiatan pengabdian kepada masyarakat dapat berjalan lancar. Persiapan materi penyuluhan, menyiapkan pemateri/narasumber, persiapan konsumsi, daftar hadir dan perlengkapan lain yang dibutuhkan terkait 
pelaksanaan kegiatan. Setelah semua sudah siap tentu juga perlu konfirmasi pada pemilik home industry akan hari, tanggal dan waktu pelaksanaan.

5.Tahap Pelaksanaan Pengabdian Kepada Masyarakat

Tahap pelaksanaan pengabdian kepada masyarakat merupakan tahap pelaksanaan penyuluhan tentang manajemen sumber daya manusia untuk pengembangan Karang Taruna Denpasar Timur, pada tahap ini tim pengusul melakukan penyuluhan sesuai tema terkait, melakukan sharing pendapat, dan mengidentifikasi kebutuhan materi yang diinginkan dan penawaran program pengabdian kepada masyarakat berkelanjutan di masa-masa yang akan datang. Langkah ini dilakukan tim pengusul agar program pengabdian kepada masyarakat ini berjalan lancar dan tepat sasaran sesuai dengan tujuan dilakukannya pengabdian kepada masyarakat.

6.Tahap Pelaporan Hasil Pengabdian

Pada tahan pelaporan hasil pengabdian kepada masyarakat ini merupakan laporan serangkaian kegiatan mulai dari surve pra pengabdian hingga pelaporan kegiatan. Hasil yang diperoleh tim pengusul diinterpretasikan agar dapat bermanfaat pagi pembaca ataupun pengguna, selain itu juga dapat referensi pengabdian berikutnya. Tentu akan dilampirkan bukti pendampingan pemetaan segmentasi pasar dan strategi pemasaran dan data hasil penjualan hasil kreatifitas bambu ini setelah ada pendampingan

\section{HASIL DAN PEMBAHASAN}

Pelatihan dan penyuluhan yang dilakukan tim Pengabdian dosen bertujuan untuk memberikan pemahaman dari manajemen SDM dalam sebuah aorganisasi karanhg taruna dan memebrikan kegiatan yang berproduksi dengan memanfaattkan silver agar mampu bertahan dan bersaing di era globalisasi dan pandemi saat ini.

Hasil dari pemberian pelatihan dan penyuluhan oleh dosen Manajemen Universitas Pamulang dan motivasi yang diberikan berupa kisah Sukses beberapa orang yang sukses dalam berwirausaha secara online dan offine serta diskusi dan Tanya jawab yang dilakukan saat kegiatan berlangsung dapat berguna bagi para pemuda Bali baik yang terikat dan yang tidak terikat dengan karang taruna sehingga dappat berproduksi secara mandiri maupun berkelompok.

Selain pemberian materi dan motivasi, tim PKM juga mengadakan praktek dan simulasi cara dagang secara daring atau online, karena pada saat ini semua lini usaha sudah merambah ke dunia online, sehingga wirausaha konvensional harus selalu siap bersaing dengan wirausaha lainnya yang sudah menguasai pemasaran secara online.

Hasil pengabdian masyarakat yang diperoleh adalah bertambahnya manajemen dan pemetaan SDM dalam Karang Taruna baik Ofline dan secara online, bertambahnya wawasan akan keilmuan SDM, karang taruna dan wirausaha, dari cerita cerita sukses pengusaha pengusaha sukses yang mulai dari nol, dan dapat menjalankan usaha dengan bekal ilmu dan wawasan mengenai kewirausahaan yang diberikan, sehingga di masa pandemi Covid-19 ini. 


\section{KESIMPULAN DAN SARAN}

Hasil dari Pelaksanaan kegiatan PKM oleh dosen-dosen Manajemen Fakultas Ekonomi Universitas Pamulang dapat membuahkan hasil yang positif terlihat dari antusias dan bersemangat para pedagang dalam mengikuti pemberian materi, simulasi, diskusi dan tanya jawab, sehingga para anggota karang taruna dapat langsung mempraktekkan cara manajemen SDM melalui media online.

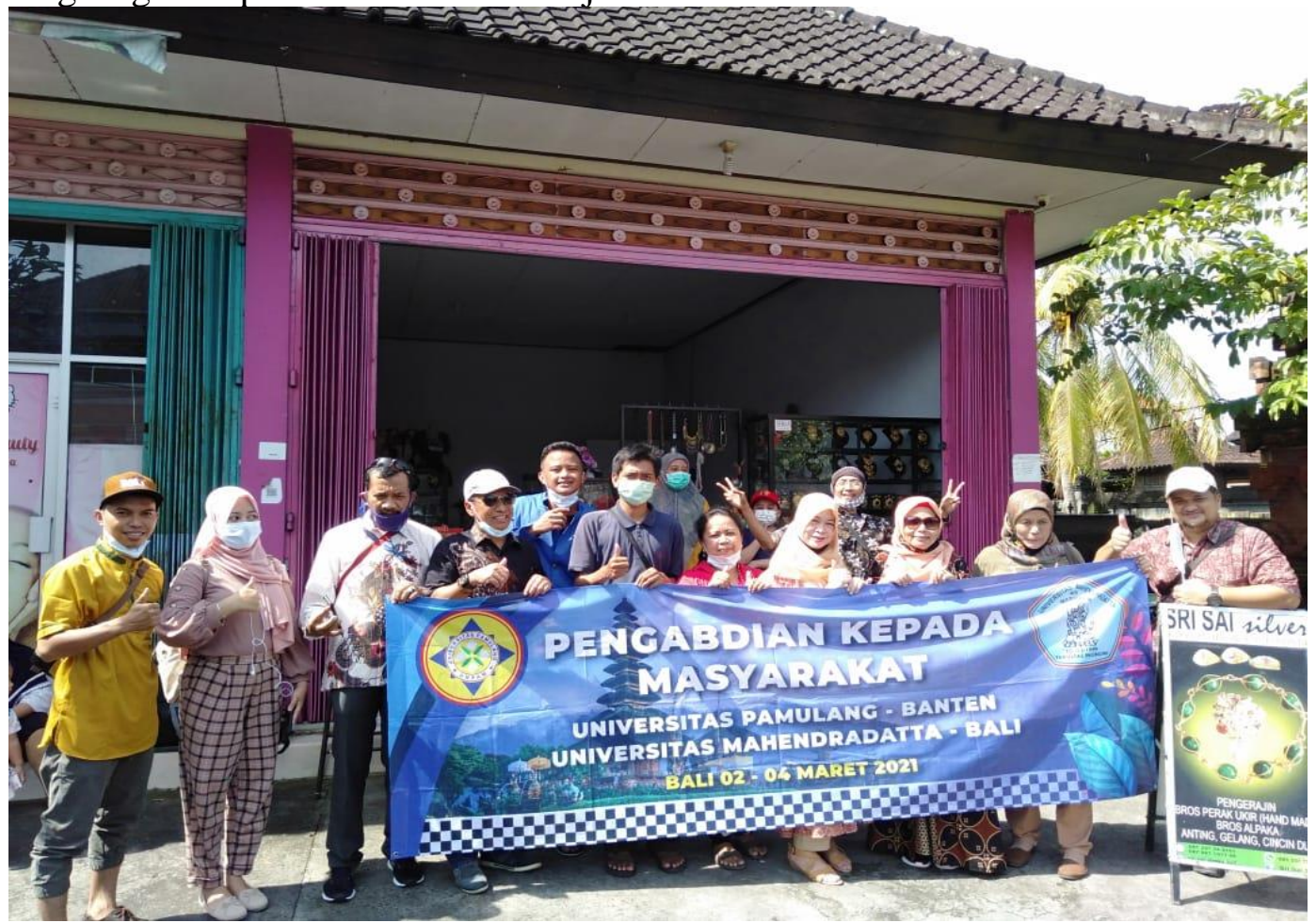

Gambar 1. Hasil PKM Bersama di Lokasi UMKM

Saran kami bagi para anggota karang taruna agar terus konsisten dalam mengevaluasi usaha secara berkala agar dapat berkembang diharapkan dalam tersusun dan bisa lebih baik lagi dalam pemantapan yang luar biasa pemetaan dan lain sebagainya.

Kami juga berharap kegiatan pengabdian kepada masyarakat di masa yang akan datang dapat lebih terprogram dan terlaksana dengan baik. Semoga kegiatan pengabdian masyarakat ini dapat bermanfaat bagi masyarakat, khususnya para anggota karang taruna Bali.

\section{DAFTAR PUSTAKA}

Ajimat, A., Sunarsi, D., \& Sidiq, F. (2020). Berwirausaha Memanfaatkan Media Sosial Pada Daerah Sepatan. ADI Pengabdian Kepada Masyarakat, 1(1), 6976.

Akbar, I. R., Sunarsi, D., Salami, M. M., Sarwani, S., \& Catio, M. (2021). Peningkatan Minat Wirausaha Pada Siswa SMK Muhammadiyah Parung Kabupaten Bogor. Jurnal PADMA: Pengabdian Dharma Masyarakat, 1(2). 
Dewanti, R. N., Supriyadi, E., Sofyan, S., Sunarsi, D., Rachmansyah, B. A., \& Yani, A. (2021). Penyuluhan Dan Pelatihan Keterampilan Sablon Pigment Pasta Manual Di Karang Taruna 03 Desa Cisauk. Jurnal PADMA: Pengabdian Dharma Masyarakat, 1(1).

Handoko, Hani. 2012. Manajemen Personalia dan Sumber Daya Manusia Edisi 2. BPFE Yogyakarta.

Lucia, Putri, Iqbal. Pengembangan Sumber Daya Manusia di Yayasan Pembangunan Masyarakat Sejahtera Kelurahan Kedaung Pamulang Tangerang Selatan. Jurnal Pengabdian DHARMA LAKSANA. Volume 1 Nomor 2 Januari 2019.

Paeno, P., Kasmad, K., Sunarsi, D., Maddinsyah, A., \& Supiyan, D. (2020). Pemanfaatan Sampah Plastik Untuk Kerajinan Rumah Tangga Taman Belajar Kreatif Mekar Sari. BAKTIMAS: Jurnal Pengabdian pada Masyarakat, 2(1), 57-61.

Sunarsi, D. (2018). Analisis Motivasi Kerja Tenaga Pendidik Sukarela Pada Pusat Kegiatan Belajar Masyarakat (PKBM) Bimasda Kota Tangerang Selatan. Kreatif: Jurnal Ilmiah Prodi Manajemen Universitas Pamulang, 6(2), 53-65. Sunasi, D., Kusjono, G., \& Nuryana, I. (2019). Pelatihan Manajemen Penguasaan Kelas Dan Pembuatan Bahan Ajar Bagi Tenaga Pengajar Sukarela Taman Belajar Kreatif Mekarsari. Jurnal Pengabdian Dharma Laksana, 2(1), 41-44. Sutrisno, 2014. Manajemen Sumber Daya Manusia. Kencana Predana Media Group. Jakarta 